\title{
FINANCIAL ANNEXATION IS CONVENTIONAL AS AN INVENTIVE PROJECTED IN ECONOMIC ASSOCIATIONS
}

\author{
Dr. Waseemullah \\ Lecturer of Finance, University of Gujrat, Gujrat, Pakistan
}

Kashif Raza*

PhD Management Science and Engineering, Dongbei University of Finance and Economics, Dalian, China.

\section{Aamir Amanat}

University Institute of Management Sciences, PMAS-Arid Agriculture University, Rawalpindi, Pakistan

Ali Usman Hali

School of Education, Shaanxi Normal University, Xi'an, China

\section{Asif Raza}

Masters of Business Administration, Riphah International University, Islamabad, Pakistan

*Corresponding Author

\begin{abstract}
Financial service providers' readiness to enter the post-Covid-19 age, with financial inclusion as a new standard in their clients' financial needs, was examined in this report. A survey was conducted as part of the study. Judgmental sampling techniques were used in the test design. Accounting firms, brokerage brokers, banking institutions, and investment funds, to name a few, were among the 117 participants in the survey. Managers in Algeria make judgments based on both insightful and inferential results. The theories were tested to a 5\% degree of validity, according to estimates. According to the results, there is a strong connection between social status and happiness. Financial identification and economic growth processes in Algeria both public and private financial institutions that are prepared to provide the necessary services and provide a conducive environment for financial technology to thrive as a driver of economic growth highly advocate incorporation as a new paradigm of financial transactions. Algeria's emerging economy is incorporating financial services.
\end{abstract}


Key words: Covid-19 pandemic; Financial inclusion; New normal; Financial service providers.

Cite this Article: Waseemullah, Kashif Raza, Aamir Amanat, Ali Usman Hali and Asif Raza, Financial Annexation is Conventional as an Inventive Projected in Economic Associations, International Journal of Management (IJM), 11(6), 2020, pp. 2180-2192. http://iaeme.com/Home/issue/IJM?Volume=11\&Issue=6

\section{INTRODUCTION}

Many countries around the world have come a long way in implementing policies to encourage and maintain financial inclusion prior to the introduction of Covid-19. This is to highlight that the concept of financial inclusion is not new in finance and accounting. With the pandemic's uncertainties, however, ways must be pursued to improve economic development through the implementation of financial inclusion, accepting its various benefits but both acknowledging and tracking its disadvantages. Algeria, as an emerging country, is one to keep an eye on, given its progress after the Central Bank of Algeria (CBN) adopted the National Financial Inclusion Strategy in 2012. The CBN emphasized primary success metrics like access to and use of a wide range of convenient and reliable financial services. Entry to and use of financial services has a significant effect on economic development in a developed economy. Financial inclusion, in financial terms, refers to the provision of financial services at affordable prices to the financially underserved community, including rural dwellers (Nwanne, 2015). Financial inclusion as a term gained traction in the early 2000s, mostly as a result of research findings that linked financial exclusion to insecurity and low economic growth in developed countries. As a result, financial isolation is the bane of economic underdevelopment advancement the push for financial inclusion was reignited by the need to provide entrepreneurs with a broad variety of financial products that are customized to their needs and available at affordable rates (Adeyinka \& Olugbamila, 2015). It is worth noting that policymakers and academics have no inkling of an impending pandemic, but with the emergence of the Covid-19 pandemic, there is a pressing need to increase advocacy for developing countries to adopt financial inclusion policies, including the need for affordability, appropriateness, and security of financial services. Scholars and policymakers have long been concerned about rural residents' access to financial resources in order to catalyze growth, alleviate poverty, and empower economic activities. The novel Covid-19 acquired popularity by imposing a crushing economic blow on every nation. That is why it is important to investigate how developing countries, especially Algeria, can use financial inclusion as a tool for economic empowerment in order to achieve economic growth and sustainability in the post-Covid-19 period. In this case, the idea of a "new standard" refers to acknowledging the fact of permanent shifts in norms and beliefs that occurred prior to the start of a new age. This is the truth of the Covid-19 pandemic, which has affected the whole world, including Algeria in particular. The review and adoption of the new standard in Algeria in terms of financial inclusion would reposition a large number of individuals, small businesses, and aspiring entrepreneurs who were previously and continue to be excluded from financial services (Mohan, 2006). According to Oluba (2008), the majority of adult Algerians in rural areas do not deal with financial institutions. This argument means that financial service providers, both private and governmental, are not widely accessible in rural areas. Financial resources are particularly lacking in Algeria, which has a population of over 200 million people, the majority of whom live in rural areas. If policies on financial inclusion are not re-designed and implemented as a new standard in the post-Covid-19 period, the strict safeguard mechanisms needed to be sustained throughout the pandemic would deal a significant blow to this great West African country's economic growth. 


\section{LITERATURE REVIEW}

In order for a country's growth to be sustainable, a range of tools must be used in order to fulfill the people's economic, social, and environmental needs. First and foremost, the quality of life of past generations must be strengthened for future generations. Financial inclusion, according to Beck, Demirgue-Kunt, Soledad, and Peria (2007), is a crucial component of, and a strategic means for, every country's financial growth. This point is backed up by the fact that it is more or less a way for businesses and households to fulfill their financial needs at fair and competitive prices by participating in the formal financial system.

According to Adeyinka and Olugbamila (2015), a country's economic growth is decided by how each sector of the economy works, and it is advised that the government of the country devise specific policies, among other items. This analysis is important because the belief that life will never be the same again after the Covid-19 pandemic is right. Physical proximity to realms and structures is performed with great vigilance in the pandemic era, with social distancing and avoidance of contact with people to avoid contracting the virus. In this sense, financial inclusion should be seen as a way of officially completing financial transactions, including payments and transfers of money, investments, insurance, and a variety of other resources that economic agents can provide. Financial inclusion, according to Nwanne (2015), encourages financial growth, and failure to describe its operations and definition can result in the actual impact of an inclusive financial system being underestimated or exaggerated. When it was discovered that a segment of society, made up of individuals and companies, was unable to obtain sufficient financial services from the major financial service providers, the idea of financial inclusion was born (Nwanne, 2015).

If one is not financially inclusive, according to Leyshon and Thrift (1995), the other side of the coin, financial exclusion, becomes essential. Financial service providers in Algeria must ensure that their customers are not financially disadvantaged if they are to embrace financial inclusion as the new standard in the post-Covid-19 period. According to Leyshon and Thrift (1995), the notion of financial isolation first surfaced in 1993, when a group of geographers conducting a study discovered how restricted access to physical banking facilities had become due to major bank branch closures. This condition deteriorated lately, as banks were forced to close their doors due to the pandemic, giving financial inclusion a boost. Singhraul and Batwe (2020) contend that the epidemic of Covid-19 has impacted human lives and resources all over the world, as numerous scholars and academics have recently shared their thoughts on the aftermath of Covid-19.

According to Singhraul and Batwe (2020), the world economy will either be boosted or depressed in the post-Covid-19 period. A country's Gross Domestic Product (GDP) can rise or fall based on how goods and services are distributed, stifling or stimulating the economy. Financial inclusion, according to Hannig and Jansen (2010), may be the trigger that ensures that any economic agent has access to basic financial services that will aid in the economy's growth. It's also a new normal that the Covid-19 pandemic has triggered financial crises in every nation on the planet, and that in order for a country's economy to survive and evolve, it must invest in financial innovation to avoid catastrophic systemic effects. International financial standard setters and financial authorities are required to work together to streamline financial standards in order to accommodate financial inclusion (Hannig \& Jansen, 2010).

Acceptance of financial inclusion will mean that individuals and companies will access and use structured financial services in their transactions in a destabilized financial system, such as the one faced during the Covid-19 pandemic (Soludo, 2008). Credit must be available and accessible at rates that were beneficial to the vulnerable and disadvantaged of society (Onaolapo, 2015). According to Sarma and Pais (2011), a financial framework is said to be egalitarian when it meets the needs of a broader range of society in a cost-effective and stable 
manner. They argue that the client's socioeconomic position cannot be taken into account if financial inclusion is to achieve its goals in the provision of services by financial service providers. As a result, Cohen, Gan, and Choong (2006) contend that when consumers are happy, the financial service provider is more likely to keep them. More specifically, there will be a trend for more effective financial capital distribution, which is supposed to fuel economic growth and development in any given setting.

Financial service providers would not be effective in implementing financial inclusion until they adopt financial technologies. This is why financial service companies must invest in the digital economy, E-commerce, and M-commerce. According to Anyalenkeya (2020), a digital economy is one that is based on digital transactions, and people who are not involved in digital financial transactions cannot be financially included. Digital infrastructure, digital channels, digital financial services, digital entrepreneurship, and digital capabilities are the five foundations of the digital economy, according to Anyalenkeya (2020). According to Adeyinka and Olugbamila (2015), the new economy is based on the internet and is not constrained by space or scope. To make this possible, both the public and private sectors in Algeria must look inwards and collaborate; otherwise, the template for financial inclusion would be zero. Ecommerce, they say, is a modern market paradigm that uses technology to promote commerce and/or provide financial services and goods to customers. It makes a living off of internet purchases, insurance, and electronic payments.

M-commerce, according to Schmitz and Grayston (2020), entails the use of mobile technology. It involves purchasing and distributing goods and services using cell phones, websites, and other mobile-friendly payment systems. Financial service providers that use financial technology solutions have an easier time implementing financial inclusion so they can give consumers better offers and avoid investing in physical infrastructure. As a result, in the post-Covid-19 era, financial inclusion fueled by financial technologies, as demonstrated by ecommerce and $\mathrm{m}$-commerce, provides customers with a wider range of goods and services that they can purchase remotely, regardless of their position. Scholars (Soludo, 2008; Swamy, 2011; Sarma \& Pais, 2011) also agree that financial inclusion in these dimensions is advantageous. Financial service providers would be able to store more information about their clients in order to provide them with more customized goods or services. The internet, cloud, smartphone, and social media have also been seen to promote digital commerce. As a result, accountants and other financial service providers must aim to stay significant in the post-Covid-19 period by reclassifying these infrastructures as properties under the new standard disposition.

\subsection{Financial Inclusion and the Idea of Intermediation}

In reality, in the post-Covid-19 period, financial intermediation as carried out by financial service providers would take a new turn. The definition, when operationalized, has the power to tie together financial providers electronically as a group, even though they are physically apart. Goal clients are often taken online to meet with them in the same way. Financial inclusion strengthens financial flows as a result of the adoption of this emerging principle of financial intermediation. According to Mohan (2006), this new idea of financial intermediation has the advantage of reducing waste when financial service companies and their customers pool money and spend less than they would have paid if they took it on their own. The benefit is that financial service companies would have more clients than they would have otherwise. Big data, Blockchain, Artificial Intelligence (AI)/machine learning, and quantum computing, according to Ojedokun (2020), are the main digital developments that will form the future economically and socially in the post-Covid-19 period. It means that financial providers, along with the community of the regional entity, must be prepared to welcome transition in order to achieve economic sustainability. In the post-Covid-19 era, digital channels will also ensure payments 
through unstructured data. Automatic Teller Machines, Supplementary Operation Details (USSD) (ATM), Points of Sale (POS) systems, among other items, are easy and convenient to use, even in rural areas. This is how the modern mode of corporate operations will be sustained economically. Accountants and other financial service firms should think about it.

\subsection{Create Activities for the New Standard}

According to Schmitz and Grayston (2020), the only factor that is known about companies and their transactions during the Covid-19 pandemic is ambiguity. Accountants and other financial service providers must brace for the post-Covid-19 environment in order to go forward and be certain of our firms. The pace at which many companies had already started their digital transitions prior to the Covid-19 period must be sustained. Countries around the world, including emerging countries, were also in the process of embracing new technical developments that would support potential market transactions. It is up to both customers and producers in this dispensation and financial service providers to welcome technological transition in order to maintain economic activity (Schnitz \& Grayston, 2020). According to Rees (2020), the Covid-19 crisis has offered service/goods suppliers and customers a look into the future. This explains why, in order to stay important in the new standard, technological implementation should be expanded to all developed countries, including Algeria, and adopted quickly. Retailers have begun to implement contactless and internet shopping/delivery, while insurance providers and tax agencies have begun to implement self-service claims review. Organizations have adopted technology that allow the bulk, if not all, of their employees to operate remotely (Schmitz \& Grayston, 2020). Rees (2020) highlighted technical mechanisms that will assist financial service firms and their clients in moving forward while mitigating the effects of the Covid-19 pandemic. Health experts are continuing to give alerts that the pandemic is spreading can become endemic; as a result, accountants and other financial service providers must take action to ensure their importance, such as:

\subsection{Concerning the Points in the Accurate Positions}

Accountants and other financial service providers, according to Rees (2020), should have access to their company details and software. Cloud apps such as Google Docs and Xero are convenient and inexpensive to use, and you should be prepared to set up an outreach team using remote access tools. The biggest impediments to successful remote working, according to Adeyinka and Olugbamila (2015), are insufficient technology and facilities. There are provisions that policymakers in developed countries, in cooperation with the regulated private sector, are required to enforce. In the long term, both the public and private sectors will benefit from it. To best implement and embrace financial inclusion based on the availability of appropriate technologies and facilities, a risk assessment must be conducted to understand the complexities of transitioning a workspace to a remote environment. The big challenge here is deciding the appropriate combination of resources to help in the transition, taking into account cyber security issues, employee well-being, competitiveness, and comfort. According to Singhraul and Batwe (2020), financial service providers must remain healthy and stable in the modern era. A technology provider recently observed more than 230,000 covid-19-related cyber-attacks, including ransom ware, company email breaches, and malicious domains, according to Rees (2020). These are the risks that culminate in a major challenge of protecting company data in financial inclusion transactions conducted on a remote basis. McEwan (2020) recommends using good anti-virus applications or other end-point defense to prevent this. Financial technology experts' advice that, in order for financial inclusion to succeed, financial service providers should also use a virtual private network (VPN), especially when workers use remote access software for on-premises systems. 
Financial service providers must stay in contact with and inspire their customers. Zoom, GoToMeeting, or Cisco Webex are preferred conferencing tools. Financial service providers are often required to maintain a balance by mitigating any feelings of alienation that workers may suffer as a result of their remote operations. As a result, these apps are used for daily team meetings in order to keep staff focused on the task at hand. Even in remote areas, chat platforms like "Slack," "Chanty," and "Workplace by Facebook" will significantly boost connectivity until the technology is in place (Rees, 2020). Another issue for financial service providers is how to successfully handle remote teams. "Remote job success depends heavily on whether workers are entrusted to the work, even though bosses do not see them," according to McEwan (2020), quoted in Rees (2020). In Algeria, for example, it is clear that the requisite gadgets will assist the financial service providers as company owners in keeping track of the actual work being performed by workers on a remote basis. The provision of resources to sustain the postCovid-19 period is still crucial to the progress of this.

Accountants and other financial service providers should learn about cloud-based market transition. Many companies would need to undergo major digital disruption in order to respond to the pandemic, and cloud applications have long-term market advantages. Migrating onpremises data to the cloud makes it easy to view files from anywhere, and it has the ability to limit or eradicate server maintenance costs. Microsoft One Disk, Google Drive, and Dropbox Enterprise are examples of systems that can do this. Accounting and finance practitioners must ensure that consumer engagement is brought to a new stage to stay relevant in the post-Covid19 period. In-person interactions are helpful, according to Rees (2020), but even at the best of times, they are not always feasible. With the introduction of conferencing technology, it is now possible to be in touch with customers more often, thus reducing travel costs for the company. Webinars have become a wonderful choice for educating consumers through apps like Zoom footage, and email newsletters are critical in the modern dispensation to keep customers updated and trained, offering answers to any problems the company organization or clients may face. It is reasonable to conclude that businesses in emerging markets that are adept at spotting opportunities and interacting with consumers on a regular basis can thrive in the new standard. Customer experience maintenance will be ensured as a result of this (CRM).

The Institute of Chartered Accountants Although CRM programs were historically developed to better handle corporate customers, emerging technologies like sales force and insight have helped market new users, according to the Institute of Chartered Accountants of Algeria (ICAN) in its 2020. Accountants' workshop on ICT. These systems provide sophisticated tools such as analytics that can be used to detect sales prospects, monitor sales personnel, and more accountants and other financial service providers should follow best practices in performance improvement. The expected change to remote working in the postCovid-19 period would require administrators to abandon conventional management methods that have struggled to adapt over time. When the dust settles, McEwan (2020) expects that our remote-working workforce will be just as efficient, if not more, than during the conventional age of handling people and jobs. Businesses who embrace technologies and advanced main success metrics are expected to know how successful their workers are and how much profit the business is achieving in the future. Schmitz and Grayston (2020) conclude that companies that excel in implementing the best technology and transitioning to flexible job conditions in the post-Covid-19 period can do well in their markets in the long run.

\subsection{Transformation in the Post-Covid-19 Period Service Providers}

According to Ojedokun (2020), digital transformation refers to the transitions that arise as emerging digital technology and market models impact the value proposition of traditional products and services. Disruption, he says, refers to a very particular mechanism that describes 
how competitors will negotiate effectively with incumbents. It has to do with business model creativity, which helps newcomers to reach the industry with low-cost, simple-to-use items. The emphasis is on the impact/influence of digital technology on culture, which may be a mixture of emerging and current innovations. This question is for society's embrace of technology as it becomes aware of the transformative experience. A technology transformation model will demonstrate how emerging disruptive technology would lead to new sources of value, which would lead to better economies. Improved economics would lead to lower marginal prices, which would boost consumer satisfaction, resulting in a higher profit margin, sales increases, and, ultimately, a higher enterprise value. However, there would be a vicious loop of market growth and expansion, in which new sources of value would fund new business models, which would then support new forms of clients and workers. The new categories of clients and staff will embrace management's new leadership models, and the trend will repeat itself to support the financial service providers' new sources of value. According to Ojedokun (2020), digital transformation should have four fundamental elements at any given level:

- A corporate philosophy that assesses the present and future demand. Plans for market growth, price policies, and the distribution of commodities or products, among other things.

- Existing technologies, including innovations, architecture, and implementation of which the latest technology would expose the company process.

- The market in which the company is based will have an impact on the procedures, current standards, potential improvements to existing standards, performance practices, and how consumers will tolerate the changes.

- The society in which the disturbance will occur is a significant consideration to remember. This has to do with the people's society and how change is received. What are their technological patterns and movements? This is what has lately been seen in many parts of the world through the $5 \mathrm{G}$ Network infrastructure revolution.

In the end, digital transformation would be helpful in the post-Covid-19 period if company owners and culture recognized the transition, financial service companies developed their brands around the latest developments, and our common future was brought to life.

\subsection{In the Post-Covid-19 Era, Audit Technology}

Many audit firms were in the process of implementing technology-enabled audit procedures, using automated client-platforms, according to Schmitz and Grayston (2020). Physical distancing has intensified the need for such technology and networks, particularly when it comes to client engagements, as shown in the Covid-19 pandemic scenario. According to Peter Kerr of the Australian National Audit Office, auditing is becoming more automated in the postCovid-19 period. "Covid-19 clearly indicates that the emphasis is moving from manual reconciliation to further automation," he added. Via digital processes, technology expedites audits." Clients, according to Hucklesby and Macdonald (2020), must be technologically up to date in order for the current normal to balance with the technology adoption by accountants and other financial service providers. In the case of an audit, the new order mandates that clients have the infrastructure in place to enable evidence to be made available to auditors.

\subsection{Theoretical Framework}

This study was based on some theories in accounting and finance, majorly, the theory of information asymmetry, and theory of financial development. The theory of information asymmetry explains the financial constraints on small firms and poor borrowers and how intermediation would ensure efficient allocation of financial resources. This happens when 
financial intermediaries are able to overcome the problems of information asymmetry (Hannig \& Jansen, 2010). Theory of financial development includes financial structure, inclusion and deepening. Financial deepening has a nexus with financial inclusion as economists use it to refer to increased provision of financial services and better access for different socio-economic groups. A deepened financial system would encourage governments and organizations to set up public sector banks that can offer pro-poor services as part of financial sector reforms. This theory ensures that a deepened financial system that is inclusive ensures both inclusive and propoor growth that is equitable. This is an aid to economic development.

\subsubsection{Empirical Framework}

Many authors have empirically studied the concept of financial inclusion at various dimensions, though a study has not yet linked the subject matter to the Covid-19 pandemic. Anyanwu (2004) empirically studied the empowerment of rural households through financial inclusion. He obtained secondary data, analyzed same and found out that there was a close relationship between financial inclusion and the empowerment of the rural dwellers. The study concluded that financial inclusion can enhance economic stimulus among economically weaker sections of a country, the rural dwellers. Murari and Didwania (2010) investigated the impact of microfinance on poverty, using financial inclusion as a catalyst. The study, conducted in India adopted the regression analysis method and analyzed the secondary data obtained from banks and primary data from 260 rural dwellers in the country who did not have incomes large enough to access banking facilities. The result indicated that financial inclusion has significant influence on poverty eradication and could provide self-employment opportunities for the poor and vulnerable in the society.

Swamy (2011) examined the trends of financial inclusion in India and found out that the number of banks is inadequate for the large rural population in India living in rural areas. It was concluded that greater number of small farmers were not included in the provision of basic financial facilities. This was believed to be responsible for the negative slope in the contribution of agriculture, the mainstay of the rural dwellers, to the Indian GDP. Sarma and Pias (2011) researching on financial inclusion and development identified the factors that had significant association with financial inclusion in cross country level. The study reveals that levels of human development in a country has a significant relationship with financial inclusion, though with few exceptions in the hypotheses tested. The study further revealed the significant relationship of financial inclusion with physical infrastructure. On the study of financial service providers, such as banks, the study however indicated that government ownership of banks was not significantly associated with financial inclusion. Onaolapo (2015) studied the effect of financial inclusion on the economic growth of Algeria. The major variables in the study were poverty reduction, and financial intermediation as indices of economic growth, while lending, means of payment and investments indicated for financial inclusion.

The study found out that there is a significant relationship between financial inclusion and Algerian economic growth. It was recommended that financial regulators in the Algerian economic space should issue proper guidelines and regulations to encourage financial intermediation among the poor rural dwellers in Algeria. Gebrehiwot and Makina (2015) researched on „financial inclusion in Africa, using GMM dynamic panel data analysis. The paper examined the determinants of financial inclusion across 27 African countries. They adopted a model which studied the problems plaguing against past studies of determinants of financial inclusion. Their model showed that financial inclusion is significantly and positively related to its lagged value, GDP per capita and mobile infrastructure, and negatively related to government borrowing. Their recommendation was that the upward trend of mobile infrastructure penetration in Africa is a welcome development and should be encouraged. In 
the same vein, the large ratio of government debt to GDP which hampers efforts to achieve financial inclusion should be minimized.

\section{METHODOLOGY}

This study adopted a survey, descriptive and causal research design. The population of the study was 150 which included accounting/audit firms, insurance companies, financial houses, central Bank of Algeria, pension fund administrators, and accounting academics. The choice of this population was based on the fact that corporate organizations, both private and government agencies in Algeria and individuals have one stake or the other in the use of financial information and devices. We had believe that their access to financial information can influence their decision about financial inclusion and increase in productivity which can enhance socioeconomic activities in the post Covid-19 era. Judgmental sampling technique was used to ensure that respondents to the administered questionnaire were drawn from the six geo-political zones of Algeria. The Taro Yamane sampling size method was used to select 109 respondents across those six geo-political zones. The total number of instruments (questionnaire) retrieved, which we gathered data from were 117, and the data were analyzed using the Pearson Moment Correlation Coefficient at a 0.05 level of significance. The hypotheses for this study were:

H1: There is no significant relationship between credit accessibility through financial inclusion and utilization of financial services by Algerians.

H2: There is no significant relationship between financial inclusion and socio-economic development in Algeria.

H3: There is no significant relationship between financial inclusion and technological development as a new normal caused by Covid-19 pandemic in Algeria.

H4: There is no significant joint relationship between audit technology, digital disruption, financial intermediation and financial inclusion.

Specifications for the Model

The above theories were evaluated using data gathered from primary sources, and after establishing that the data gathered had a causal link, we needed to look for signs of strong correlation. The general regression equation is:

$\mathrm{Y}=\mathrm{f}(\mathrm{X})$, indicating that $\mathrm{Y}$ depends on $\mathrm{X}$, and the equation is written as:

$$
\mathrm{Y}=\alpha+\beta_{1} x_{1}+\beta_{2} x_{2}+\beta_{3} x_{3}+\mu
$$

Where, $\alpha$ is the intercept, and $\beta_{1}, \beta_{2}, \beta_{3}$ are the coefficients of the variables respectively, which show the kind of relationship between dependent and independent variables and $\mu$ is known as the error term. Therefore,

$\mathrm{Y}=$ Dependent variable, which is Financial inclusion.

$\mathrm{X}=$ Independent variable, which is financial technology transactions and it is indicated by: Audit Technology, Digital Disruption and Financial Intermediation.

For this study, we adapted the formula as follows:

Financial inclusion $=f($ Financial Technology transactions $)$.

i.e. $F I=f(F T)$

So,

$$
F I=a_{0}+\beta_{1} A T+\beta_{2} D D+\beta_{3} F N+\mu
$$

Where,

$A T=$ Audit technology.

$D D=$ Digital disruption. 
FN = Financial intermediation .

\subsection{Hypothesis Research and Review}

SPSS was used to assess hypotheses one through three. The contingent variable, interest in publicly listed firms, was opposed to the independent variable, innovative accounting proxies. The judgment rule was to deny the null hypothesis if the estimated probability, $p$, was less than the alpha value of $0.05(\mathrm{p}<0.05)$ and agree if not.

\section{FINDINGS AND RESULTS}

The tables and conclusions from the study, along with the related results, are shown in this section.

Table 1 The Relationship Between Financial and Correlation Analysis Sub-variables in Transactions and Financial Inclusion

\begin{tabular}{|c|c|c|c|c|c|}
\hline Correlation & \multicolumn{2}{|c|}{ F INCLUSION } & \multirow{2}{*}{$\frac{\mathbf{A T}}{0.77}$} & \multirow{2}{*}{$\begin{array}{c}\text { DD } \\
0.156\end{array}$} & \multirow{2}{*}{$\begin{array}{c}\text { FN } \\
0.843\end{array}$} \\
\hline & F INCLUSION & 1 & & & \\
\hline & AT & 0.77 & 1 & 0.082 & 0.734 \\
\hline & DD & 0.156 & 0.082 & 1 & -0.096 \\
\hline & FN & 0.843 & 0.734 & -0.096 & 1 \\
\hline \multirow[t]{4}{*}{ Sig. ( 1-tailed) } & F INCLUSION & & 0 & 0.115 & 0 \\
\hline & $\mathrm{AT}$ & 0 & . & 0.265 & 0 \\
\hline & $\mathrm{DD}$ & 0.115 & 0.265 & & 0.23 \\
\hline & FN & 0 & 0 & 0.23 & Pearson \\
\hline \multirow[t]{4}{*}{$\mathrm{N}$} & F INCLUSION & 117 & 117 & 117 & 117 \\
\hline & $\mathrm{AT}$ & 117 & 117 & 117 & 117 \\
\hline & DD & 117 & 117 & 117 & 117 \\
\hline & FN & 117 & 117 & 117 & 117 \\
\hline
\end{tabular}

Source: SPSS V.20 Field Data Analysis (2020).

The data are provided with tables and evaluated, using SPSS Package. In table 1, the entire pair wise correlation coefficients represent the real significance degree for each correlation. The table indicates that financial inclusion correlates with Audit Technologies (AT) at 0.77, suggesting a strong degree of association (roughly 77 percent). The $\mathrm{p}$-value is also smaller than the alpha standard (p0.05), as seen in the table. At 0.000, this was important. The null hypothesis 1 was dismissed, and the alternative hypothesis was accepted, using our judgment law. This suggests that there is a clear correlation between credit affordability and Algerians' use of financial resources as a result of financial inclusion.

Hypothesis 2 focused on Algeria's financial inclusion and socioeconomic development. When Digital Disruption is used as a sub-variable of Financial Technology Transactions, the correlation is 0.16 , which is a negligible 16 percent relationship. The calculated $p$, however, is greater than the alpha level ( $\mathrm{p} 0.05$ ), as shown in the table. As a result, null hypothesis 2 is accepted according to our decision rule.

Hypothesis 3 on financial inclusion and technological development as a new normal in Algeria caused by the Covid-19 pandemic was also tested. The relationship has a $\mathrm{r}$ of 0.84 , indicating an 84 percent significant correlation. The null hypothesis was rejected using our decision rule because the calculated $p$-value was less than the alpha value (p 0.05). This indicates that there is a strong link between financial inclusion and financial intermediation. 
Financial Annexation is Conventional as an Inventive Projected in Economic Associations

Table 2 Analysis of Variance (ANOVA) associated with Multiple Regressions

\begin{tabular}{|c|c|c|c|c|c|c|c|c|c|}
\hline \multirow[t]{2}{*}{ Model } & \multicolumn{2}{|c|}{$\begin{array}{l}\text { Sum of } \\
\text { Squares }\end{array}$} & df & $\begin{array}{l}\text { Mean } \\
\text { Square }\end{array}$ & $\mathbf{F}$ & \multirow[t]{2}{*}{$\mathbf{R}$} & \multirow[t]{2}{*}{$\mathbf{R}^{2}$} & $\begin{array}{c}\text { Adjusted } \\
\mathbf{R}^{2}\end{array}$ & \multirow[t]{2}{*}{ Result } \\
\hline & Regression & 59.262 & 4 & $\begin{array}{l}14.81 \\
6\end{array}$ & & & & & \\
\hline & Residual & 10.475 & 56 & 0.187 & & & & & \\
\hline & Total & 69.738 & 60 & & $\begin{array}{l}79.203 \\
0.922^{* *}\end{array}$ & & 0.850 & 0.839 & $\begin{array}{l}0.000 \\
\text { Significant }\end{array}$ \\
\hline
\end{tabular}

**Dependent variable: Investment. *Independent variable: AT, DD, FN. Source: SPSS V.20 Field Data Analysis (2020).

Table 2 shows analysis of variance (ANOVA) which indicates that when the multiple correlation is converted to $\mathrm{F}$, it shows an $\mathrm{F}$ ratio of 79.20 that is significant at 0.000 . This depicts that all the sub-variables of financial technology transactions in this study when jointly regressed against financial inclusion had a lower $p$-value than the alpha value $(p<0.05)$. A multiple correlation coefficient, $\mathrm{R}$ of 0.922 was also realized, indicating a very high correlation. The $\mathrm{R}^{2}$ value of 0.850 indicates that all the independent variables combined contribute about $85 \%$ to financial inclusion. Therefore, with a lower p-value of 0.000 which is lower than the 0.05 value, the null hypothesis 4 was rejected. This implies that there is significant joint relationship between audit technology, digital disruption, financial intermediation and financial inclusion.

Table 3 Coefficients of the Joint Relationship between variables of Financial Technology Transactions and Financial Inclusion

\begin{tabular}{|c|c|c|c|c|c|c|c|}
\hline \multirow[t]{2}{*}{ Model } & \multicolumn{2}{|c|}{$\begin{array}{c}\text { Unstandardized } \\
\text { Coefficients }\end{array}$} & \multirow{2}{*}{$\begin{array}{c}\begin{array}{c}\text { standardized } \\
\text { Coefficients }\end{array} \\
\text { Beta } \\
\end{array}$} & \multirow[b]{2}{*}{$\begin{array}{l}\text { Lower } \\
\text { Bound }\end{array}$} & \multirow{2}{*}{$\begin{array}{c}95 \% \\
\text { Confidence } \\
\text { Interval for B } \\
\text { Upper Bound } \\
\end{array}$} & & \\
\hline & B & $\begin{array}{l}\text { Std. } \\
\text { Error }\end{array}$ & & & & $\mathbf{t}$ & Sig. \\
\hline (Constant) & -1.034 & 0.3256 & & -1.534 & -0.634 & -3.972 & 0 \\
\hline $\mathrm{AT}$ & -0.016 & 0.0897 & -0.017 & -0.219 & 0.186 & 0.265 & 0.834 \\
\hline $\mathrm{DD}$ & 0.079 & 0.0634 & 0.083 & -0.034 & 0.183 & 0.214 & 0.213 \\
\hline FD & 0.598 & 0.0852 & 0.723 & 0.632 & 0.794 & 0.943 & 0 \\
\hline
\end{tabular}

Source: SPSS V.20 Field Data Analysis (2020)

Table 3 shows the coefficients of the joint relationship between variables of financial technology transactions adopted for this study and financial inclusion. The regression shows a significant relationship (0.000) in the overall, though the relationship of AT and DD do not show significant values. The Beta for AT is -0.014 (not significant, $p>0.05$ ), 0.094 for DD (not significant, $\mathrm{p}>0.05$ ).

\section{CONCLUSION}

The findings of this study indicate that, in the end, financial technology transfers have a significant association with financial inclusion. The null hypothesis 2 was previously agreed before arriving at this multiple association finding between the independent and dependent variables. This means that, for the time being, financial inclusion and socioeconomic development in Algeria do not appear to be related. This hypothesis, however, will not hold true in light of the future and events in the financial technology space. 


\subsection{Suggestions}

The authors of this study recommend that Algerian governments (federal and state) in charge of the public sector economy create an enabling environment for financial technology to thrive as a driver of financial inclusion. The private sector, which includes investors and financial service providers, should recognize that in today's competitive world, most investors will close shop to their competitors if they refuse to adapt to technological advancements. Algeria's socioeconomic development indices are still very low. Rural residents, who make up the majority of the population, must actively participate. Small-scale entrepreneurs, in particular, who are known to make significant contributions to economic development, should be encouraged to be financially inclusive.

\section{REFERENCES}

[1] Adeyinka, S. A. and Olugbamila, O. B. (2015). Public private participation for infrastructure in developing countries. Academic Journal of Interdisciplinary Studies. 4(2): 11-18.

[2] Anyalenkeya, B. (2020). Emerging business trends and technologies. Paper delivered at the Institute of Chartered Accountants of Algeria Webinar series in the Faculty of consultancy \& ICT (Lagos, Algeria, June 30, 2020).

[3] Anyanwu, C. M. (2004). Microfinance institutions in Algeria: Policy, practice and potentials. Central Bank of Algeria paper presented at the G24 workshop on "Constraints to growth in the Sub-Saharan Africa" November 29-30, 2004. http://www.g24.org/anyanwu.pdf.

[4] Beck, T., Demirgue-Kunt, A., Soledad, M. and Peria, M. (2007). Reading out: Access to and use of banking services across countries. Journal of Financial Economics. 85(1): 234-266.

[5] Cohen, D., Gan, C., and Chong, E. (2006). Customer satisfaction: A study of Bank customer retention in New Zealand. Commerce Division Discussion Paper, No. 109, p19. https://researcharchive.lincoln.ac.nz/bitstream/handle/10182/324/cd_dp_109.pdf.

[6] Gebrehiwot, K. G. and Makina, D. (2015). Financial inclusion in Africa: Evidence using dynamic panel data analysis. Researchgate.net publication. DOI=10.13140/RG.2.1.1711.7929.

[7] Hannig, A. and Jansen, S. (2010). Financial inclusion and financial stability: Current policy issues. SSRN Electronic Journal. DOI = http://doi.10.2139/ssrn.1729122.

[8] Hucklesby, M., Macdonald, J. (2004). The three tenets of XBRL - adoption, adoption, adoption! Chartered Accountants Journal of New Zealand 83 (1): 46-47.

[9] Leyshon, A. and Thrift, N. (1995). Geographies of financial exclusion: Financial abandonment in Britain and United States. Transactions of the Institute of British

[10] Geographers. Journal of the Royal Geographical Society. DOI=10.2307/622654. https://www.jstor.com/stable/622654.

[11] McEwan, A. (2020). Upcycle, upskill and unite - three ways for leaders to survive Covid-19. Available at: https://www.insidehr.com.au/author.

[12] Mohan, R. (2006). Economic growth, financial deepening and financial inclusion. Address at the Annual Bankers' Conference. Hyderabad, November 3, 2006.

http://rbidocs.rbi.org.in/rdocs/speeches/pdf/73697.pdf. 
[13] Murari, K. and Didwania, M. (2010). Poverty alleviation through financial inclusion: An analytical study with special reference to India. Revelation: The Research Journal of K.P.B. Hinduja College of Commerce, India. 2(3): 60-72.

[14] Nwanne, T. F. I. (2015). Relationship between financial inclusion and economic growth in Algerian rural dwellers. International Journal of Small Business and Entrepreneurship Research. 3(7): 17-27.

[15] Ojedokun, O. (2020). Exploiting disruption in the digital world. Paper presentation at the Institute of Chartered Accountants of Algeria Webinar Series, Faculty of Consultancy and Information Technology. June 30, 2020.

[16] Oluba, M. (2008). Who should provide public infrastructure in Algeria? http://www.proshereng.com.

[17] Onaolapo, A. R. (2015). Effects of financial inclusion in the economic growth of Algeria. International Journal of Business and Management Review. 3(8): 11-28.

[18] Rees, G. (2020). Tech tools can help you and your business deal with the impact of Covid-19, now and in the long-term. Available at: https://intheblack.com/articles.

[19] Sarma, M. and Pais, J. (2011). Financial inclusion and development. Journal of International Development. 23: 613-628. Available at: https://doi.org/10.1002/ji d.1698.

[20] Schimitz, J. and Grayston, C. (2020). What are finance professionals and business leaders considering as they plan for the new normal in the recovery phase? https://intheblack.com/articles.

[21] Singhraul, B. P. and Batwe, Y. (2020). Corona virus: An economic cataclysm or a visual aid to the lucrative growth in India. Test Engineering and Management, a publication of Mattingley Publishing Co., Inc. 83: 381-389.

[22] Soludo, C. C. (2008). Making finance work for the poor. A lecture delivered at the Federal University of Technology, Owerri, Imo State, Algeria.

http://www.cenbank.org/out/speeches/2008/Govadd25-2-08.pdf.

[23] Swamy, V. P. (2011). Financial inclusion in India. An evaluation of the coverage, progress and trends. The IUP Journal of Financial Economics. 9(2): 7-26. 